\title{
Chlorpyrifos biodegradation in relation to metabolic attributes and 16S rRNA gene phylogeny of bacteria in a tropical vertisol
}

\author{
Usha Ahirwar $^{1} \cdot$ Bharati Kollah $^{1} \cdot$ Garima Dubey $^{1} \cdot$ Santosh Ranjan Mohanty ${ }^{1}$
}

(C) Springer Nature Switzerland AG 2019

\begin{abstract}
It is predicted that use of insecticide chlorpyrifos will increase in near future due to intensive agricultural practice and climate change. The present study envisages establishing linkages among biodegradation potential, carbon metabolism and enzymatic attributes of bacteria involved in chlorpyrifos biodegradation. Soil samples from an experimental field were incubated with chlorpyrifos ( $10 \mathrm{\mu g} \mathrm{g}^{-1}$ soil). Chlorpyrifos biodegradation rate was $0.34 \pm 0.04 \mathrm{ug} \mathrm{g}^{-1}$ soil d $^{-1}$. Culturable bacteria were isolated and identified by 16 S rRNA gene sequencing. DNA sequences were $96-100 \%$ similar to the GenBank bacterial DNA sequences. The bacterial community was predominated by Arthrobacter phenanthrenivorans (23\%). Followed by Arthrobacter globiformis and Bacillus flexus represented 15\% each. Microbacterium paraoxydans, Bacillus megaterium, Bacillus soli strain R, Bacillus drentensis, and Bacillus koreensis represented $8 \%$ of total bacteria. The carbon source utilization pattern and enzymatic activities of the bacterial isolates were estimated. The isolates preferred to metabolize trehalose and mannose over other $C$ sources. These bacteria exhibited decarboxylase, oxidase, catalase, cellulose, deaminase and nitrate reductase activities. A PCA analysis based on various metabolic attributes explained $32.49 \%$ variance by PC1 and $16.46 \%$ variance by PC2. PCA highlights that the bacterial isolates placed distantly from those of simple sugar utilizers, probably use chlorpyrifos as $C$ substrate. Correspondence analysis outlaid decarboxylase, catalase, and oxidase as the key enzymatic activities of the bacterial isolates for chlorpyrifos biodegradation.
\end{abstract}

Keywords Chlorpyrifos · Microbial metabolism · Soil · Phylogeny · 16S rRNA

\section{Introduction}

Pesticides are widely used in agriculture to protect crops from disease causing pests. The applied pesticides reach target pests by only $1 \%$ while the remaining portion is transformed into various complex metabolites [12]. The insecticide chlorpyrifos (0,0-diethyl-3,5,6-trichloro-2- pyridylphosphorothioate) is widely used for treatments of crops, lawns, and ornamental plants [39]. This broad-spectrum insecticide is used against a variety of insects including mosquitoes (larvae and adults), flies, and ecto-parasite of cattle and sheep [17]. Chlorpyrifos suppresses acetylcholinesterase [10], and leads to various clinical effects in human beings [13]. Chlorpyrifos may affect the endocrine system, respiratory system, cardiovascular system, nervous system, immune system, as well as the reproductive system due to its high mammalian toxicity [36].

Soil microbial groups including nitrifies, denitrifies, N fixers and $P$ solubilizer's are adversely affected by chlorpyrifos application. In a study the population of asymbiotic nitrogen fixing bacteria was greatly decreased over the years (2009-2013) after the chlorpyrifos treatment [16]. Similar negative effect was observed with symbiotic $\mathrm{N}$ fixers [35]. The chlorpyrifos metabolites 3,5 , 6-trichloro-2- pyridinol (TCP), has been found to inhibit major soil microbial groups [24]. Phosphate solubilisation was found un-affected after application of chlorpyrifos in paddy soil over the years (2009-2013) [16]. Chlorpyrifos and other insecticides (carbofuran, thiomethoxam, imidacloprid) inhibit phosphate solubilising

Santosh Ranjan Mohanty, santosh.mohanty@icar.gov.in | 'ICAR Indian Institute of Soil Science, Nabibagh, Bhopal 462038, India.

SN Applied Sciences (2019) 1:228 | https://doi.org/10.1007/s42452-019-0206-0 
bacteria [28]. Chlorpyrifos also inhibits beneficial plant growth promoting microorganisms in soil [2]. In natural ecosystem chlorpyrifos is degraded to diethylthiophosphoric acid (DETP) and 3,5,6-trichloro-2-pyridinol (TCP) [25].

Microbial degradation of chlorpyrifos has become the focus of many studies because other methods of removing chlorpyrifos residues are impractical or costly or are themselves environmentally hazardous. Many endophytic bacteria degrade chlorpyrifos [29].

Degradation of the pesticide depends upon the type of the soil, soil property, moisture content and pH of soil [22]. Therefore, the organisms isolated from one soil may not be effective in the in other soil to biodegrade chlorpyrifos. To date, several microbial species have been isolated from chlorpyrifos contaminated soil and their efficiency towards biodegradation has been studied. However, in natural ecosystem, series of microbial groups with different functionalities carry out chlorpyrifos biodegradation. Thus use of single strain in bioremediation of chlorpyrifos is questionable. To enhance the biodegradation potential of soil, there is need of comprehensive understanding of the microbial community undertaking chlorpyrifos biodegradation. This study is based on hypotheses that the bacteria involved in chlorpyrifos biodegradation have complex $C$ source utilization properties and enzymatic activities. The complex metabolic attributes of microorganisms play key role in the biodegradation of chlorpyrifos.

\section{Materials and methods}

\subsection{Soil sampling and physico-chemical characteristics}

Experiments were carried out using soil samples collected from the experimental fields of ICAR-Indian Institute of Soil Science (IISS). The institute is located at Bhopal, Madhya Pradesh, India. The geographical position is $23^{\circ} 18^{\prime} \mathrm{N}$ latitude and $77^{\circ} 24^{\prime} \mathrm{E}$ longitude. The mean annual air temperature remains about $25^{\circ} \mathrm{C}$ and the annual rainfall occurs approximately $1200 \mathrm{~mm}$. Humidity remains around $56 \%$. This location experiences southwestern monsoon rains season during July to September. The experimental soil is classified as Vertisol. The soil belongs to Hypothermic family of Typic Haplusterts. Commonly the soil is referred as "black cotton soil". The soil was characterized by $5.7 \mathrm{~g} \mathrm{~kg}^{-1}$ organic carbon, $225 \mathrm{mg} \mathrm{kg}^{-1}$ available $\mathrm{N}, 230 \mathrm{mg} \mathrm{kg}^{-1}$ available $\mathrm{K}$ and $2.6 \mathrm{mg} \mathrm{kg}^{-1}$ available $\mathrm{P}$, the electrical conductivity (EC) was $0.43 \mathrm{dS} \mathrm{m}^{-1}$ and soil pH was 7.5. The soil composition and textural were: sand $15.2 \%$, silt $30.3 \%$ and clay $54.5 \%$.

\section{SN Applied Sciences

\subsection{Chlorpyrifos biodegradation}

The chlorpyrifos (Sigma Aldrich, USA) stock solution of $1000 \mathrm{ppm}$ which is generally prepared in organic solvents [5]. For the current study acetonitrile was used for stock preparation as it is a very good solvent in HPLC analysis. The chlorpyrifos stock of $0.1 \mathrm{ml}$ was added to $130 \mathrm{ml}$ presterilized serum vials. These vials represented the treatments of $10 \mathrm{ppm}(\mathrm{w} / \mathrm{w})$ chlorpyrifos. To nullify the effect of solvent on microbial activity vials were kept open overnight to evaporate acetonitrile completely. To each vial $20 \mathrm{~g}$ portion of soil was placed. The soils were moistened with sterile distilled water to provide $60 \%$ moisture holding capacity (MHC) and allowed to equilibrate with the ambient air for $3 \mathrm{~d}$ in the dark in an incubator at $30 \pm 2^{\circ} \mathrm{C}$. The contents of the vials were mixed thoroughly, capped with rubber septa and sealed using aluminum crimp seal. Vials were incubated at three different temperatures of $25 \pm 2{ }^{\circ} \mathrm{C}$, in separate biological oxygen demand incubators (Metrex scientific instruments pvt Itd, New Delhi, India).

\subsection{Chlorpyrifos extraction and analysis}

Soil samples of about $5 \mathrm{~g}$ were taken out from the vials at different incubation period ( 0 day, 15 day, 30 day). Chlorpyrifos was extracted following the protocol as described somewhere else (Mallick et al. [15]). The soil samples were transferred to $250 \mathrm{ml}$ of volumetric flask and $25 \mathrm{ml}$ of distilled water was added to soils maintained at $60 \%$ MHC. Acetone $50 \mathrm{ml}$ added and flasks were shaken for $1 \mathrm{~h}$ in an orbital shaker. In case of soil samples maintained at $100 \%$ $\mathrm{MHC}$, the extraction procedure was similar as described above except that distilled water was not added. After $1 \mathrm{~h}$ of equilibration with acetone, $20 \mathrm{ml}$ of hexane was added to these flasks and the contents were again shaken for $1 \mathrm{~h}$. To the flasks sodium sulphate ( $2 \%$ of the total) was added and volume made up to $250 \mathrm{ml}$ with distilled water. Upper layer $(\sim 5 \mathrm{ml})$ of hexane was taken out into a sterile glass vial and the vials were kept open overnight to evaporate at room temperature. The residue was dissolved in $1 \mathrm{ml}$ acetonitrile and used for analysis. Chlorpyrifos was analyzed in a HPLC (High Performance Liquid Chromatography). Analysis was performed at wavelength of $325 \mathrm{~nm}$ using mixture of acetonitrile and $0.1 \%$ of aqueous Ortho phosphoric acid at a ratio of 75:25 as the mobile phase with a flow rate of $1 \mathrm{ml} \mathrm{min}{ }^{-1}$. The HPLC system used was a Varian Prostar instrument equipped with degasser, quaternary pump, UV detector connected to a Rheodyne injection system ( $20 \mathrm{~mL}$ loop). The stationary phase was comprised of Lichrospher on C-18-packed stainless steel column $(250 \mathrm{~mm} \times 4 \mathrm{~mm}$ i.d). 


\subsection{Isolation of chlorpyrifos degrading bacteria}

To isolate bacteria soil samples following chlorpyrifos degradation were processed. About $1 \mathrm{~g}$ soil sample from the vial was suspended in $10 \mathrm{ml}$ sterile distilled water. Soil suspension was serially diluted up to $10^{-8}$ dilutions, and $100 \mu \mathrm{l}$ of this suspension was spread on the Mineral salts medium (MSM) [37]. The medium prepared by dissolving $1.8 \mathrm{~g} \mathrm{~K}_{2} \mathrm{HPO}_{4}, 4.0 \mathrm{~g} \mathrm{NH}_{4} \mathrm{Cl}, 0.2 \mathrm{~g} \mathrm{MgSO}_{4} .7 \mathrm{H}_{2} \mathrm{O}, 0.1 \mathrm{~g} \mathrm{NaCl}$, $0.01 \mathrm{~g} \mathrm{FeSO}_{4} .7 \mathrm{H}_{2} \mathrm{O}$, in $1 \mathrm{~L}$ of distilled water. Chlorpyrifos (filter sterilized by passing through $0.2 \mu \mathrm{M}$ syringe filter) was added to the MSM media at a final concentration of $10 \mathrm{ppm}$. Media and chlorpyrifos were mixed thoroughly by swirling the flask in hand. Plates were prepared and inoculated following aseptic condition. Plates were incubated at $28 \pm 2{ }^{\circ} \mathrm{C}$ in an incubator for $24-48 \mathrm{~h}$. Number of colonies appeared on the plates were counted to determine the bacterial abundance. Colonies having unique morphological features were further streaked on the plates. The purified isolates were stored in slants at $4{ }^{\circ} \mathrm{C}$.

\subsection{Characterization of isolates}

Approximately 50 uniform bacterial colonies per plate emerged on all of the plates. On the basis of colony color and structure, 17 isolates were screened and grown on fresh nutrient agar media. Stock cultures were maintained on nutrient slopes and sub-cultured every 8 weeks. Bacterial morphology and motility were studied with a phase-contrast microscope (Leica, Germany). Gram staining was performed using a Himedia Gram stain kit (India). Testing for $C$ source utilization was performed by standard high media disc protocol. Different $C$ sources were used to determine the $C$ utilization pattern of the isolates. The $C$ sources included monosaccharides (arabinose, cellubiose, glucose, dextrose, dulcitol, fructose, galactose, mannitol, mannose, xylose, rhamnose, lactose) disaccharides (sucrose, melibiose, and maltose), trisaccharides (trehalose), tetrasaccharide (raffinose, rhaminose), polysaccharides (inositol, melibiose, salicin, sorbitol, inulin). Catalase activity was determined by observing bubble production in $3 \%(v / v), \mathrm{H}_{2} \mathrm{O}_{2}$ and oxidase activity was determined using $1 \%$ $(\mathrm{m} / \mathrm{v})$ tetramethyl-p-phenylenediamine. Nitrate reduction or nitrate utilization was performed by colorimetric assay using sulfanilic acid and a-naphthylamine. Phenyl alkaline deaminase and tryptophan decarboxylase activity was performed by following standard methods [4].

\subsection{PCR amplification of 165 rRNA gene and sequencing}

The bacterial pure cultures isolated from the soils under degradation studies were identified phylogenetically. Colonies were subjected to colony PCR using the forward primer
341F (5'-TAC GGG AGG CAG CAG -3') and reverse primer 907R (5'-CCG TCA ATT CCT TTR AGT TT-3') (Xcelris labs Itd, Ahmedabad) to amplify the partial 16S rRNA gene. The reaction mixture included master mix $10 \mu \mathrm{l}$, forward and reverse primer $0.1 \mu \mathrm{l}$ taq polymerase $0.2 \mu \mathrm{l}$ and $39.6 \mu \mathrm{l}$ water was added and volume of reaction made $50 \mu \mathrm{l}$. The PCR was run in Stepone ${ }^{\mathrm{TM}}$ realtime PCR thermocycler (Applied Biosystems, USA). The reaction conditions were: an initial denaturation step at $94{ }^{\circ} \mathrm{C}$ for $5 \mathrm{~min}$, annealing $45^{\circ} \mathrm{C}$ for $30 \mathrm{~s}$, elongation $72^{\circ} \mathrm{C}$ for $45 \mathrm{~s}$. PCR was carried out for 40 cycles. After completing the $P C R$, the $P C R$ product was purified using PCR purification kit with spin columns according to the manufacturer's (BR Biochem, N Delhi) instructions. Then these samples were sent for sequence analysis in IISER, Bhopal (M.P.). Both forward and reverse sequences were matched by global alignment and contigs were created by the CAP contig assembly tool of BioEdit ver 7.2.5.

\subsection{S rRNA sequence alignment and phylogenetic analysis}

After sequencing the qualities of the DNA sequence (electrophoregrams) were first checked manually to detect th defective (presence of ambiguous assignments of nucleotides) sequences. Chimera Check program was used to remove the chimeric sequences. The program available at NCBI (http://www.ncbi.nlm.nih.gov/) was used for this analysis. Sequences were aligned with the help of RDP (Ribosomal database project) database. The closest similarities were matched by using the Seqmatch program of RDP. The DNA sequences were grouped into single related groups based on their similarity values ( $\geq 98 \%$ similar to one another). The DNA sequences having unambiguous nucleotides were used for analysis. After alignment with RDP database, the closely related sequences were retrieved from RDP. These sequences were used to construct phylogenetic tree. Based on the maximum identity score, most closely related sequences were selected. These sequences were aligned using the multiple alignment program Muscle of MEGA 7. A distance matrix was generated and a phylogenetic tree was constructed by the neighbour-joining algorithm [32]. The stability of the phylogenetic trees was tested with sets of 100 re-samplings using bootstrap program (MEGA 7).

\subsection{Statistical analysis}

Isolates were clustered based on the basis of their carbohydrate metabolism pattern. A data matrix was created by assigning positive growth of the isolates as 1 and no growth as 0 . Data was subjected to cluster analysis using the brays-curtis distance measure. Dendrogram was constructed using an un-weighted pair-group method with arithmetic mean using the statistical software PAST (ver 
2.12). To identify the major isolates and their response to carbohydrates, Principal Component Analysis (PCA) was carried out. PCA analysis was interpreted graphically by constructing biplots, with the original variables drawn as vectors that summarize the correlation among the variables. Correspondence analysis was carried out to exhibit the inter-relation among the isolates and the biochemical properties. PCA and correspondence analysis was performed using the agricolae and vegan package of the statistical software $\mathrm{R}$ ver 2.15.1.

\section{Results}

\subsection{Chlorpyrifos degradation}

The concentration of chlopyrifos was measured at $0 \mathrm{~d}$, $15 \mathrm{~d}$ and $30 \mathrm{~d}$ of incubation period (Table 1). Data are

Table 1 Chlorpyrifos biodegradation potential of soil (vertisol)

\begin{tabular}{ll}
\hline Days of incubation & $\begin{array}{l}\text { Chlorpyrifos } \\
\left(\mu \mathrm{g} \mathrm{g}^{-1} \text { soil }\right)\end{array}$ \\
\hline 0 & $9.74 \pm 0.28^{\mathrm{a}}$ \\
15 & $4.70 \pm 0.36^{\mathrm{b}}$ \\
30 & $3.15 \pm 0.23^{\mathrm{c}}$ \\
Tukeys HSD $(p<0.05)$ & 0.31 \\
\hline
\end{tabular}

Soils were incubated with chlorpyrifos $\left(10 \mu \mathrm{g} \mathrm{g}^{-1}\right.$ soil) and incubated at $60 \%$ moisture holding capacity. Concentration of chlorpyrifos was estimated at 0,15 and 30 days of incubation. For all sample $n=3$. Values with same letter are not statistically different at $p<0.05$ presented as arithmetic mean \pm standard deviation of 3 replicated observations. At $0 \mathrm{~d}$, chlorpyrifos concentration was $9.74 \pm 0.28 \mathrm{\mu g} \mathrm{g}^{-1}$ soil. Concentration of chlorpyrifos declined about $50 \%$ at $15 \mathrm{~d}$ and about $30 \%$ at $30 \mathrm{~d}$. Deg-

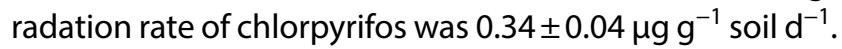

\subsection{Diversity of culturable bacteria}

Culturable count of the chlorpyrifos biodegrading bacteria ranged from $4.2 \pm 0.701 \times 10^{5}$ colony forming unit (CFU) $\mathrm{g}^{-1}$ dry soil. In chlorpyrifos un-amended soil bacterial count was about $35 \times 10^{6} \mathrm{CFU} \mathrm{g}^{-1}$ soil. Based on the colony morphology 17 bacterial isolates were selected for $16 \mathrm{~S}$ rRNA sequences analysis. The classification of the $16 \mathrm{~S}$ rRNA genes of the bacterial isolates is given in Table 2. The PCR amplicons were 812 bp to 902 bp length. Sequences were $96-100 \%$ homologous to the known bacterial species (NCBI GenBank database). The sequences mainly represented Alphaproteobacteria, Betaproteobacteria, Firmicutes, and Actinobacteria. The sequences had GC content in the range of $52.2-56.6 \%$. A pie chart constructed to exhibit relative abundance of different bacterial species (Fig. 1). The most dominant bacteria was Arthrobacter phenanthrenivorans (23\%). Followed by Arthrobacter globiformis and Bacillus flexus were present at $15 \%$ each. Microbacterium paraoxydans, Bacillus megaterium, Bacillus soli strain R, Bacillus drentensis, and Bacillus koreensis were present at $8 \%$ each. Uncultured Bacillus $s p$ constituted of $7 \%$ of the total bacterial population.
Table 2 The $16 \mathrm{~S}$ rRNA gene phylogeny of chloryrifos degrading heterotrophic bacteria isolated from vertisol

\begin{tabular}{lllllc}
\hline Isolates & Classification & $\begin{array}{l}\text { Microorganism with most closest } \\
\text { sequence in GenBank database }\end{array}$ & GC & Base pair & Similarity (\%) \\
\hline C1 & Aphaproteobacteria & Microvirga vignae & 55.8 & 817 & 99 \\
C2 & Aphaproteobacteria & Microvirga lupini & 56.4 & 812 & 99 \\
C3 & Betaproteobacteia & Vogesella perlucida & 52.2 & 868 & 99 \\
C4 & Betaproteobacteria & Cupriavidus taiwanensis & 55.4 & 867 & 98 \\
C5 & Aphaproteobacteria & Microvirga subterranea & 55.8 & 824 & 100 \\
C6 & Betaproteobacteria & Cupriavidus taiwanensis & 55.6 & 862 & 98 \\
C7 & Aphaproteobacteria & Sphingopyxis indica & 53 & 819 & 99 \\
C8 & Aphaproteobacteria & Microvirga vignae & 56.6 & 821 & 99 \\
C9 & Aphaproteobacteria & Microvirga subterranea & 55.8 & 814 & 98 \\
C10 & Fermicutes & Bacillus simplex & 53.4 & 902 & 99 \\
C11 & Aphaproteobacteria & Microvirga lupini & 56.2 & 827 & 98 \\
C12 & Fermicutes & Bacillus safensis & 55.4 & 891 & 99 \\
C13 & Actinobacteria & Microbacterium resistens & 56 & 878 & 98 \\
C14 & Fermicutes & Bacillus safensis & 55.4 & 892 & 100 \\
C15 & Fermicutes & Bacillus simplex & 54.1 & 891 & 99 \\
C16 & Fermicutes & Paenibacillus purispatii & 54.1 & 889 & 96 \\
C17 & Actinobacteria & Micrococcus aloeverae & 56.6 & 844 & 99 \\
\hline
\end{tabular}




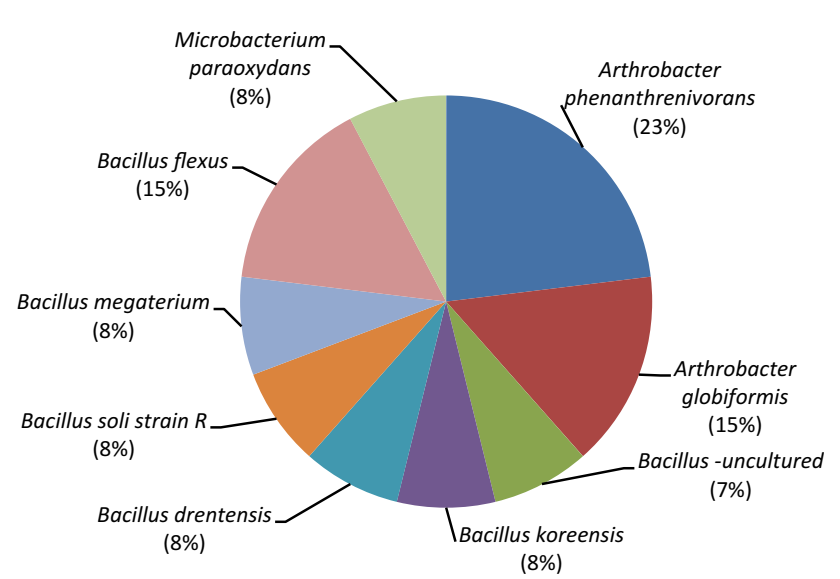

Fig. 1 Diversity of chlorpyrifos biodegrading bacteria in vertisol. Genomic DNA was extracted from the bacteria isolated from soil after degradation of chlorpyrifos. PCR amplification performed targeting 165 rRNA gene. DNA sequences were aligned with 16S rRNA gene database and closest relatives identified using Blastn algorithm of NCBI. Values in parenthesis represent percentage abundance of bacterial isolates

\subsection{Phylogenetic characteristics}

Molecular phylogenetic analysis of the 16S rRNA genes of the bacterial isolates is given in Fig. 2. The bacterial isolates $\mathrm{C} 1, \mathrm{C2}, \mathrm{C} 5, \mathrm{C} 9$ were closely related to Microvirga species. The isolates $\mathrm{C} 4, \mathrm{C} 6$ isolates were similar to Cuprividus $s p$. The bacterial isolate $\mathrm{C} 7$ isolate showed similarity with Sphingophyxis $s p$. The isolates $\mathrm{C} 10, \mathrm{C} 12, \mathrm{C} 14, \mathrm{C} 15, \mathrm{C} 16$ isolates were related to various Bacillus $s p$ and Paenibacillus $s p$. The isolate $\mathrm{C} 13$ was mostly homologous to Microbacterium sp. The strain $\mathrm{C} 17$ strains showed similarity with Micrococcus alveroence.

\subsection{Cellular and biochemical characterization}

Various cellular and biochemical properties of the bacterial isolates is presented in Table 3. The population of chlorpyrifos biodegrading bacteria was comprised of both gram positive and gram negative type at a equal proportion. Bacterial colonies were mostly non pigmented, and in the shades of white or yellow. Majority of the isolates were rod shaped. About $62.66 \%$ of the isolates were motile. The optimal $\mathrm{pH}$ of the medium was 6-7 for the growth of the isolates. Approximately $88 \%$ of the isolates were catalase positive. About $65-70 \%$ of the isolates reduced nitrate. Approximately $60 \%$ isolates hydrolyzed starch. Most of the isolates showed decarboxylase activity. Among these isolates Microvirga and Micrococcus species showed deaminase activity.

The bacterial isolates varied in their $C$ source utilization metabolism (Table 4). Among the different $C$ sources trehalose and mannose were the most preferred $C$ sources and approximately $60 \%$ of isolates utilized them. Dextrose, glucose and cellulose, salicin, xylose, arabinose, fructose, adonitol were used by $55 \%$ of the isolates. Melibiose, sucrose, mannitol were the least (10-20\%) utilized C source. Galactose, sorbitol or dulcitol were un-utilized by the isolates.

\subsection{Statistical analysis}

Carbon utilization pattern of the isolates were further characterized by Brays-curtis dendrogram (Fig. 3). Bacteria were grouped into three major clusters. Cluster I constituted of $\mathrm{C} 5, \mathrm{C} 6, \mathrm{C} 8, \mathrm{C} 17, \mathrm{C} 4, \mathrm{C} 7$, and $\mathrm{C} 3$. These isolates were mostly specific to utilize few $C$ sources. Cluster II was constituted of $\mathrm{C} 11, \mathrm{C} 16$, and $\mathrm{C} 2$. Cluster III constituted of $\mathrm{C} 12, \mathrm{C} 14, \mathrm{C} 15, \mathrm{C} 9, \mathrm{C} 11, \mathrm{C} 10$, and C13. Isolates of cluster II preferred glucose and fructose and cluster III preferred polysaccharides. PCA indicated that the most of the data variance was explained by the first two principal components (Fig. 4). First component (PC1) explained $32.49 \%$ variance and PC2 caused $16.46 \%$ variance. PCA highlighted that the isolate $\mathrm{C} 10, \mathrm{C} 16, \mathrm{C} 2$, and $\mathrm{C} 1$ were capable of utilizing a wide variety of $C$ sources. Other isolates (placed away from the $C$ sources) differed in terms of $C$ source utilization. Correspondence analysis revealed that bacterial isolates vary significantly in terms of their enzymatic activities (Fig. 4). The component 1 contributed 35.4\% variation while the component 2 contributed $30.4 \%$ variation. Most of the isolates had decarboxylase, cellulose, catalase, and oxidase activities.

\section{Discussion}

Biodegradation of chlorpyrifos and the bacteria involved in this process are well studied $[2,14,31]$. However, biodegradation of chlorpyrifos in relation to the metabolic nature of bacterial community is not explored. Therefore, this experiment was carried out to (1) evaluate biodegradation potential of chlorpyrifos, (2) characterize bacterial species involved in the chlorpyrifos biodegradation in terms of $C$ utilization and enzymatic activities and (3) define the relation between metabolic attributes of bacterial isolates and chlorpyrifos degradation potential. Chlorpyrifos biodegradation in vertisol occurred within 15 days of incubation which agrees with earlier reports. The half life of chlorpyrifos has been found to be 1.7-24 days in rice field soil [1]. Total culturable bacterial abundance was within a range as observed earlier [9]. Chlorpyrifos reduced bacterial abundance in soil as it inhibits microorganisms. For example, chlorpyrifos inhibits aerobic bacteria [26], N cycling microbes [2] and microbial biomass [34]. Occurrence of bacterial colonies on the agar plates indicated 
Fig. 2 Molecular phylogenetic analysis of chlorpyrifos biodegrading bacteria based on $16 \mathrm{~S}$ rRNA gene sequences. The evolutionary history was inferred using the UPGMA method. The optimal tree with the sum of branch length $=1.21368557$ is shown. The percentage of replicate trees in which the associated taxa clustered together in the bootstrap test $(100$ replicates) are shown next to the branches. The tree is drawn to scale, with branch lengths in the same units as those of the evolutionary distances used to infer the phylogenetic tree. The evolutionary distances were computed using the Maximum Composite Likelihood method and are in the units of the number of base substitutions per site. The analysis involved 50 nucleotide sequences. All positions containing gaps and missing data were eliminated. There were a total of 583 positions in the final dataset. Evolutionary analyses were conducted in MEGA7

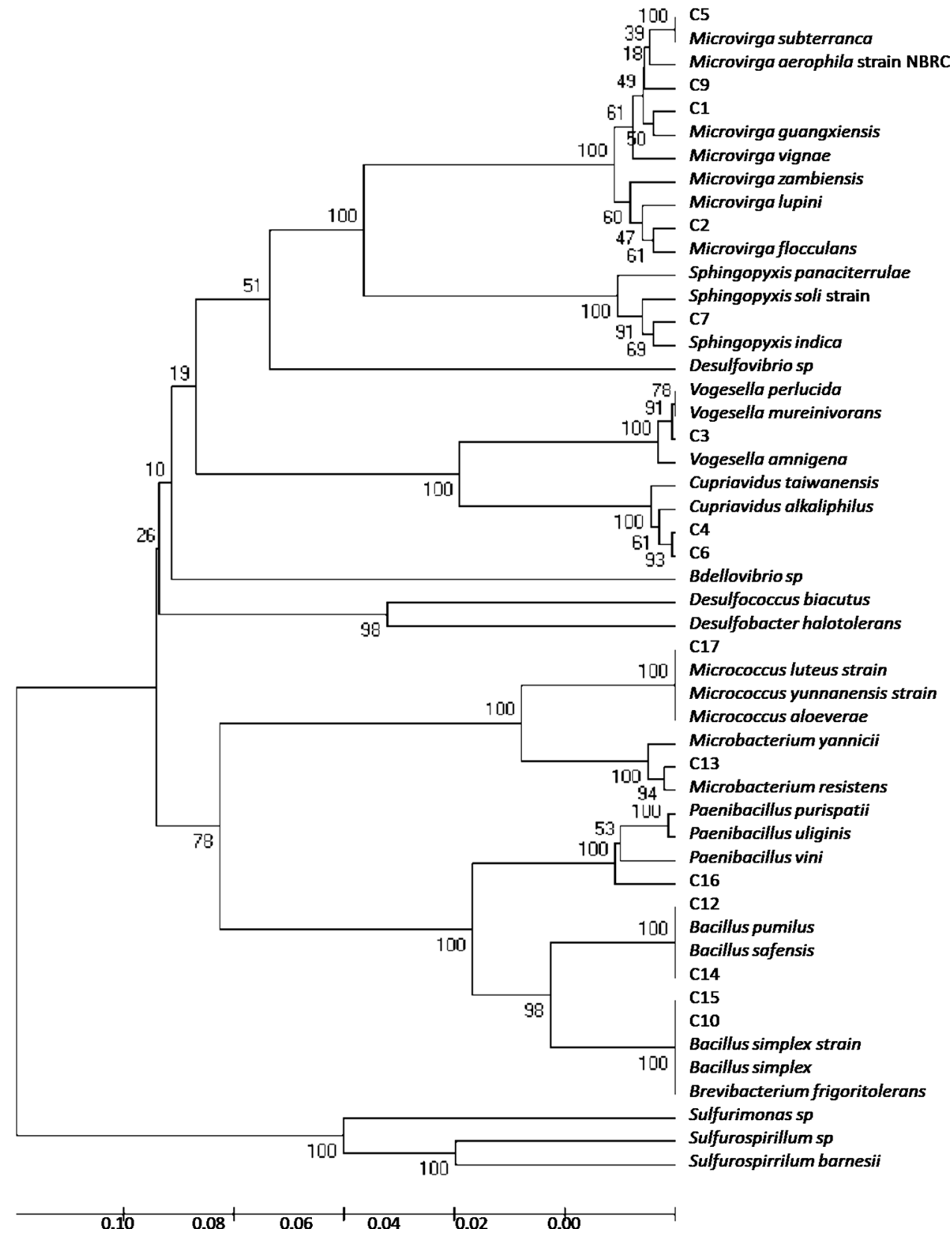

that several species of bacteria were involved in the chlorpyrifos biodegradation.

The $16 \mathrm{~S}$ rRNA sequences of the isolates matched with GenBank sequences of Alphaproteobacteria, Firmicutes and Actinobacteria. Similar result has been observed in Punjab soil [2]. Among different isolates, Microvirga was the most prominent representing $35 \%$ of bacterial population. The next abundant bacteria were Bacillus sp 23\%, and Cuprividus sp 12\%. The lowest abundant bacteria were Sphingopyxis, Vogesella, Paenibacillus, Microbacterium, and Micrococcus each of $6 \%$ of total bacterial population. Microvirga has been found in soil treated with chlorpyrifos. This species multiplies by producing pesticide-degrading enzymes like organophosphorus hydrolase (OPH) [13], and phosphotriesterase. These enzymes are extracellular in nature [33]. The intermediates of chlorpyrifos biodegradation are TCP and DETP. These compounds are produced by the hydroxylation reaction [19]. Cupriavidus taiwanensis has been isolated from the sludge of drain outlet of a chlorpyrifos manufacturer. This species was capable of transforming chlorpyrifos to 3,5,6-trichloro-2-pyridinol (TCP) [18]. Sphingomonas $s p$ utilizes chlorpyrifos as sole source of carbon for growth, by hydrolyzing chlorpyrifos to 3,5,6-trichloro2-pyridinol (TCP) [11]. Bacillus or paenibacillus groups catalyzed chlorpyrifos through hydrolysis of $\mathrm{C}-\mathrm{O}-\mathrm{P}$ ester bonds by phosphatase or phytase enzymes and released soluble 
Table 3 Metabolic and biochemical attributes of chlorpyrifos degrading bacteria isolated from vertiso

Table 4 Sugar utilization pattern of chlorpyrifos degrading bacteria isolated from vertisol

\begin{tabular}{|c|c|c|c|c|c|c|c|c|c|c|c|c|c|c|c|c|c|}
\hline \multirow[t]{2}{*}{ Characteristics } & \multicolumn{17}{|c|}{ Bacterial isolates } \\
\hline & $C_{1}$ & $\mathrm{C}_{2}$ & $\mathrm{C}_{3}$ & $\mathrm{C}_{4}$ & $C_{5}$ & $\mathrm{C}_{6}$ & $C_{7}$ & $\mathrm{C}_{8}$ & $\mathrm{C}_{9}$ & $C_{10}$ & $\mathrm{C}_{11}$ & $\mathrm{C}_{12}$ & $\mathrm{C}_{13}$ & $\mathrm{C}_{14}$ & $\mathrm{C}_{15}$ & $C_{16}$ & $\mathrm{C}_{17}$ \\
\hline orp & RS & RS & RS & RS & RS & RS & RS & RS & RS & RS & RS & RS & RS & RS & RS & RS & C \\
\hline lour & NP & NP & NP & W & LP & W & LP & NP & LP & W & W & W & W & W & W & $\mathrm{TP}$ & $Y$ \\
\hline ram & - & - & - & - & - & - & - & - & - & + & - & + & \pm & + & + & + & + \\
\hline Motility & - & - & + & + & - & + & - & - & - & + & - & + & - & + & + & - & - \\
\hline Oxidase & - & + & - & - & + & - & - & - & + & + & + & + & + & + & + & - & - \\
\hline Catalase & - & + & + & + & + & + & + & + & + & + & + & + & + & + & + & - & + \\
\hline Nitrate utilization & + & + & + & + & + & + & + & + & - & + & + & - & - & - & - & + & - \\
\hline Starch (cellulase) & - & + & + & + & + & - & + & - & - & + & - & - & + & - & + & + & + \\
\hline Decarboxylase & + & + & + & - & + & + & + & - & - & - & + & + & + & + & - & + & - \\
\hline Deaminase & - & - & - & - & - & - & - & - & - & - & + & - & - & - & - & - & + \\
\hline
\end{tabular}

RS round shaped, CCocci, NP non pigmented, LPlight pigmented, WWhite, TP transparent, Yyellow $\mathrm{C}_{1}=$ Microvirga vignae, $\mathrm{C}_{2}=$ Microvirga lupine, $\mathrm{C}_{3}=$ Vogesella perlucida $\mathrm{C}_{4}=$ Cupriavidus taiwa $\mathrm{C}_{5}=$ Microvirga subterrana, $C_{6}=$ Cupriavidus taiwa $C_{7}=$ Sphingophyxis indica, $C_{8}=$ Microvirga vignae, $C_{9}=$ Microvirga substerrana, $\mathrm{C}_{10}=$ Bacillus simplex, $\mathrm{C}_{11}=$ Microvirga lupine, $\mathrm{C}_{12}=$ Bacillus safensis, $\mathrm{C}_{13}=$ Microbacterium resistence, $C_{14}=$ Bacillus safensis, $C_{15}=$ Bacillus simplex,$C_{16}=$ Paenibacillus $C_{17}=$ Micrococcus aloverance + Positive for growth; - no growth

Sugars Bacterial isolates

\begin{tabular}{lllllllllllllllll}
\hline $\mathrm{C} 1$ & $\mathrm{C} 2$ & $\mathrm{C} 3$ & $\mathrm{C} 4$ & $\mathrm{C} 5$ & $\mathrm{C} 6$ & $\mathrm{C} 7$ & $\mathrm{C} 8$ & $\mathrm{C} 9$ & $\mathrm{C} 10$ & $\mathrm{C} 11$ & $\mathrm{C} 12$ & $\mathrm{C} 13$ & $\mathrm{C} 14$ & $\mathrm{C} 15$ & $\mathrm{C} 16$ & $\mathrm{C} 17$
\end{tabular}

\begin{tabular}{|c|c|c|c|c|c|c|c|c|c|c|c|c|c|c|c|c|c|}
\hline Glu & + & + & + & + & - & - & + & - & + & + & - & - & - & - & - & - & - \\
\hline $\mathrm{De}$ & + & + & + & - & - & - & - & - & + & + & + & - & + & - & - & + & + \\
\hline Fc & - & - & - & - & - & - & - & + & - & + & - & - & + & - & - & + & + \\
\hline $\mathrm{Su}$ & - & - & - & - & - & - & - & - & - & + & - & - & + & - & - & - & + \\
\hline $\mathrm{Ce}$ & + & - & - & - & - & - & + & - & - & + & - & + & + & + & - & + & - \\
\hline $\mathrm{Du}$ & - & - & - & - & - & - & - & - & - & - & - & - & - & - & - & - & - \\
\hline $\mathrm{Ad}$ & + & + & - & - & - & - & - & - & - & + & - & - & - & - & - & + & - \\
\hline $\mathrm{Ar}$ & - & + & - & - & - & - & - & - & - & - & - & + & - & + & - & + & - \\
\hline In & - & - & - & - & - & - & - & - & - & - & - & - & - & - & - & + & - \\
\hline Sa & + & + & + & - & - & - & + & - & - & - & - & - & + & - & + & - & - \\
\hline $\mathrm{Mb}$ & + & - & + & - & - & - & - & - & - & - & - & - & - & - & - & + & - \\
\hline Is & + & - & - & - & - & - & - & - & - & - & - & - & - & - & - & - & - \\
\hline $\mathrm{Ga}$ & - & - & - & - & - & - & - & - & - & - & - & - & - & - & - & - & - \\
\hline Xy & - & + & - & - & - & - & + & - & - & - & + & - & + & - & - & - & - \\
\hline La & + & - & - & - & - & - & - & - & - & - & - & - & - & - & - & + & - \\
\hline $\mathrm{Sb}$ & - & - & - & - & - & - & - & - & - & - & - & - & - & - & - & - & - \\
\hline $\mathrm{Mn}$ & - & - & - & - & - & - & - & - & - & - & - & - & - & - & + & - & - \\
\hline $\mathrm{Te}$ & + & + & - & - & - & - & - & - & + & + & + & + & + & + & + & + & - \\
\hline Mo & + & + & - & - & - & - & - & - & + & + & + & + & + & + & + & + & - \\
\hline $\mathrm{Rf}$ & + & + & - & - & - & - & - & - & - & - & - & - & - & - & - & + & - \\
\hline $\mathrm{Rh}$ & + & + & - & - & - & - & - & - & - & - & - & - & - & - & - & - & - \\
\hline $\mathrm{Ma}$ & + & + & + & - & - & - & - & - & - & - & - & - & - & - & - & + & - \\
\hline
\end{tabular}

Sugars: Gluglucose, Dedextrose, Fcfructose, Su Sucrose, Cecellubiose, Du dulcitol, Adadonitol, Ararabinose, In inuline, Sa salicin, Mb melibiose, Is inositol, Gagalactose, Xyxylose, Lalactose, Sb sorbitol, Mn mannitol, Te trehalose, Mo mannose, Rfraffinose, Rh Rhamanose, Ma maltose

The bacterial isolates: $C_{1}=$ Microvirga vignae, $C_{2}=$ Microvirga lupine, $C_{3}=$ Vogesella perlucida $C_{4}=$ Cupriavidus taiwa $\mathrm{C}_{5}=$ Microvirga subterrana, $\mathrm{C}_{6}=$ Cupriavidus taiwa $\mathrm{C}_{7}=$ Sphingophyxis indica, $\mathrm{C}_{8}=$ Microvirga vignae, $C_{9}=$ Microvirga substerrana, $C_{10}=$ Bacillus simplex,$C_{11}=$ Microvirga lupine, $C_{12}=$ Bacillus safensis, $\mathrm{C}_{13}=$ Microbacterium resistence, $\mathrm{C}_{14}=$ Bacillus safensis, $\mathrm{C}_{15}=$ Bacillus simplex, $\mathrm{C}_{16}=$ Paenibacillus $\mathrm{C}_{17}=$ Micrococcus aloverance

+ Positive for growth; - no growth 


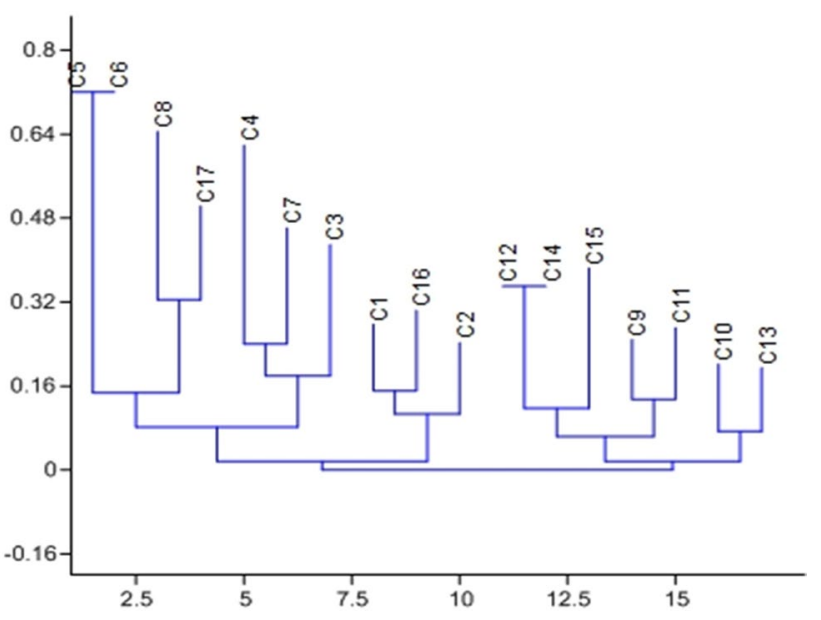

Fig. 3 Bray-Curtis similarity of the chlorpyrifos biodegrading bacteria based on their carbohydrate utilization pattern. The isolates are named as $\mathrm{C}$ followed by a number. The isolates with similar carbon-metabolizing activity were clustered within same nod. The bacterial isolates are as follows : $C_{1}=$ Microvirga vignae, $\mathrm{C}_{2}=$ Microvirga lupine, $\mathrm{C}_{3}=$ Vogesella perlucida $\mathrm{C}_{4}=$ Cupriavidus taiwa $\mathrm{C}_{5}=$ Microvirga subterrana, $\mathrm{C}_{6}=$ Cupriavidus taiwa $\mathrm{C}_{7}=$ Sphingophyxis indica, $\mathrm{C}_{8}=$ Microvirga vignae, $\mathrm{C}_{9}=$ Microvirga substerrana, $\mathrm{C}_{10}=$ Bacillus simplex, $\mathrm{C}_{11}=$ Microvirga lupine, $\mathrm{C}_{12}=$ Bacillus safensis, $C_{13}=$ Microbacterium resistence, $C_{14}=$ Bacillus safensis, $C_{15}=$ Bacillus simplex, $\mathrm{C}_{16}=$ Paenibacillus $\mathrm{C}_{17}=$ Micrococcus aloverance

phosphorous and carbon for their energy source [20]. Micrococcus species belong to group of bacteria those adapt readily to contaminated environments. Therefore, these bacteria are potentially useful for bioremediation purposes [21]. It was found that Micrococcus degrade chlorpyrifos up to $76 \%$ [30]. The phylogenetic analysis highlighted relatedness of the bacterial isolates with the known (reference) species. The un-related isolates branched separately from the known sequences of GenBank.

Carbohydrate metabolism pattern varied among the bacterial isolates. Most of the isolates readily utilized monosaccharide like mannose and xylose and disaccharides like trehalose, cellubiose. However, the isolates feebly utilized disaccharides (sucrose, maltose, melibiose), polysaccharide (inulin), and sugar alcohols (inositol and sorbitol). Monosaccharides found to be the driving factors for chlorpyrifos degradation in vertisol. Therefore, bacterial community had functional groups which could metabolites polysaccharides resulting simpler sugars to degrade chlorpyrifos. Similar result has been observed where simple glucose and maltose promoted chlorpyrifos degradation and produced non toxic compound like 2-pyridinol and thiophosphate [27]. Based in the $C$ source utilization pattern it is plausible that the biodegradation of chlorpyrifos occurred by group of bacteria having different metabolic attributes, by the bacterial groups which use complex $C$ sources (polysaccharides) and then by the bacterial groups which preferentially use simpler $C$ sources (monosaccharide or disaccharide). Probably, bacteria using sugar alcohols participate in the degradation of chlorpyrifos at the intermediate stage. There were an equal proportion of Gram-positive and Gram negative bacteria in the soil sample. Most of the bacterial isolates were catalase positive, oxidase positive and also showed motilily. Motility reflects microbial virility and effectiveness to grow under adverse or stress environmental conditions. Similar results have been observed in other studies [9].

Principal component analysis (PCA) differentiated the bacterial isolates based on their $C$ source utilization pattern. Most of the isolates were distantly related to the tested $C$ sources indicating preferential use of chlorpyrifos as $C$ substrate. Many bacterial species has been isolated from soil capable of using chlorpyrifos as $C$ source [6]. The isolates $\mathrm{C} 1, \mathrm{C} 2, \mathrm{C} 10$, and $\mathrm{C} 16$ were closely placed with the C sources. Probably, these species use the metabolites (sugars) from the breakdown of polysaccharides (cellulose). The isolates C4, C5, C6, and C7 representing Cupriavidus sp, Microvirga, and Sphingopyxis sp are well known chlorpyrifos biodegrading organisms prevalent in soil. Cupriavidus has been used as inoculants to remediate chlorpyrofos contaminated soil. [18]. Microvirga belongs to the Methylobacteriacea. Many members of this family degrade different organic pollutants [7]. Therefore, this study is the first to report Microvirga $s p$ as a possible degrader of chlorpyrifos. Sphingopyxis $s p$ is a known organophosphate insecticide biodegrader [8].

The chlorpyrifos biodegradation pathway involves 4 steps. In the 1 st step chlorpyrifos is rapidly converted to chlorpyrifos oxon by oxidative desulfuration by mixedfunction oxidases. The 2 nd step is the conversion of chlorpyrifos directly to 3,5,6-trichloro-2-pyridinol (TCP) and diethyl thiophosphate. The 3rd step is the hydrolysis of chlorpyrifos to monethyl 3, 5, 6- trichloro-2-pyridinyl phosphorothioate. However, this is a minor reaction pathway. In the 4th step chlorpyrifos oxon gets deactivated to TCP by hydrolysis. The toxicity of TCP increases in soil as its half life is 65 and 360 days in soil [23] In a study on the degradation of chlorpyrifos in aqueous solution hydrolysis, oxidation, hydroxylation and decarboxylation has been found to contribute to the degradation reaction and the degradation pathway for the insecticide [38]. Therefore, the correspondence analysis indicated that the bacterial isolates were closely related to decarboxylase, catalase, cellulase, nitrate reduction, and oxidase activities.

Catalase and oxidase hydrolyze chlorpyrifos by cleaving $\mathrm{P}-\mathrm{O}, \mathrm{P}-\mathrm{F}$, and $\mathrm{P}-\mathrm{S}$ bonds. Therefore, most bacterial isolates exhibited these enzymatic activities. The isolates also had decarboxylase activity, which indicated that chlorpyrifos degradation could have progressed through removal of $C$ 
Fig. 4 Top-PCA bilot (top) where the variation rendered by $\mathrm{PC} 1$ and $\mathrm{PC} 2$ was $32.49 \%$ and $16.46 \%$ respectively. Glu Glucose, De Dextrose, Fc fructose, Su Sucrose, CeCellubiose, Du Dulcitol, Ad Adonitol, Ar Arabinose, In Insulin, Sa Salicin, Mb Melibiose, Is inositol, Ga Galactose, Xyxylose, La Lactose, Sb Sorbitol, Mn Mannitol, TeTrehalose, Mo Mannose, RfRaffinose, Rh Rhamanose, Ma Maltose. Correspondence analysis (bottom) from a binary matrix of the enzymatic (Catalase, oxidase, decarboxylase, cellulose, nitrate reduction, and deaminase) activities exhibited by the chlorpyrifos degrading bacteria isolated from vertisol. The bacterial isolates are as follows: $\mathrm{C}_{1}=$ Microvirga vignae, $\mathrm{C}_{2}=$ Microvirga lupine, $\mathrm{C}_{3}=$ Vogesella perlucida $\mathrm{C}_{4}=$ Cupriavidus taiwa $\mathrm{C}_{5}=$ Microvirga subterrana, $\mathrm{C}_{6}=$ Cupriavidus taiwa $\mathrm{C}_{7}=$ Sphingophyxis indica, $\mathrm{C}_{8}=$ Microvirga vignae, $C_{9}=$ Microvirga substerrana, $\mathrm{C}_{10}=$ Bacillus simplex, $\mathrm{C}_{11}=$ Microvirga lupine, $\mathrm{C}_{12}=$ Bacillus safen sis, $\mathrm{C}_{13}=$ Microbacterium resistence, $\mathrm{C}_{14}=$ Bacillus safensis, $\mathrm{C}_{15}=$ Bacillus simplex, $\mathrm{C}_{16}=$ Paenibacillus $\mathrm{C}_{17}=$ Micrococcus aloverance

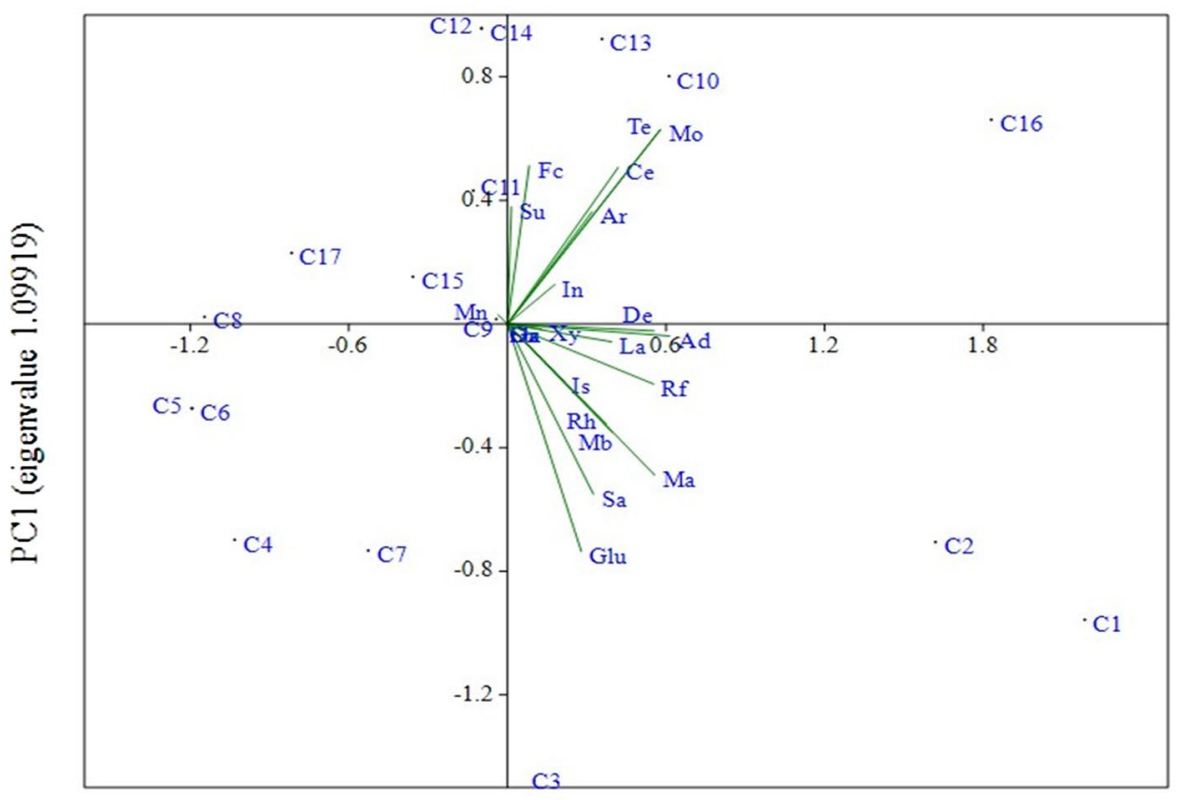

PC2 (eigenvalue 0.556807 )

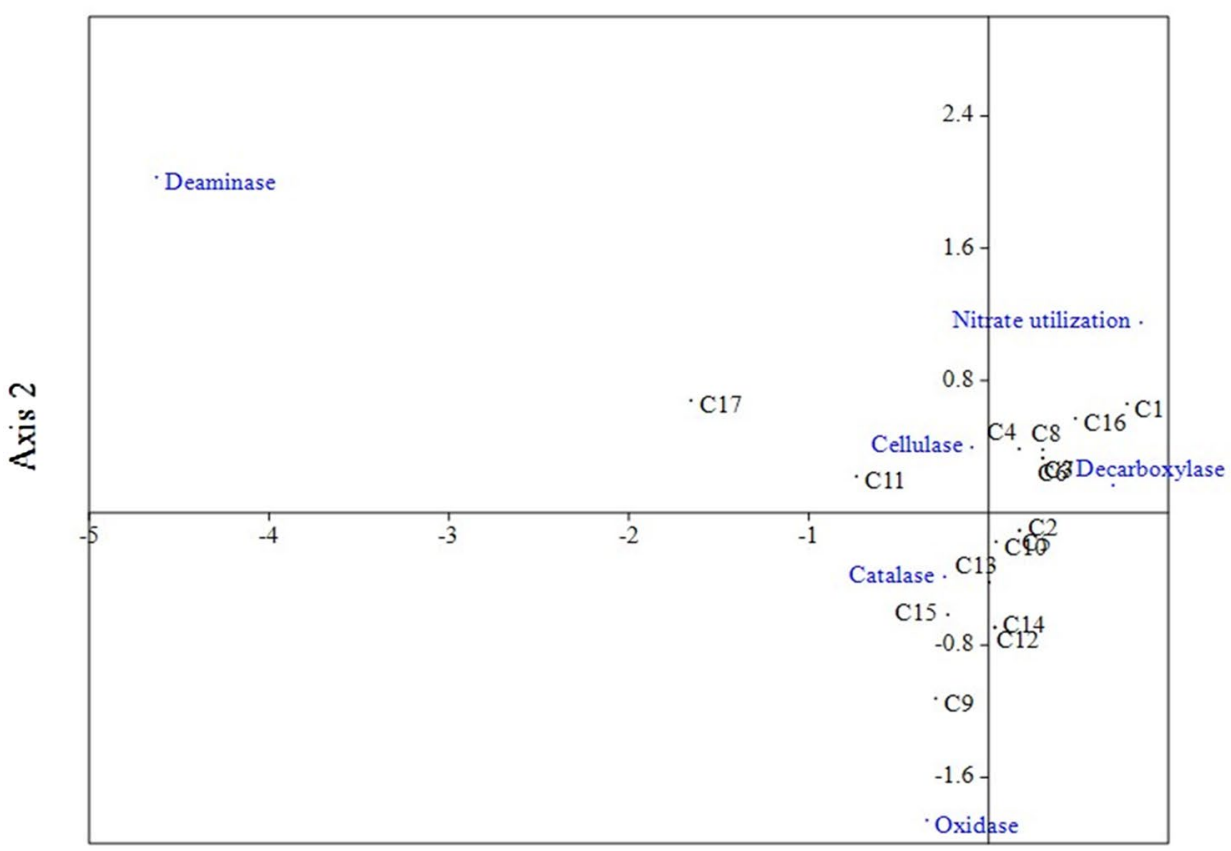

Axis 1 through aerobic respiration. Energy for these enzymatic activities was met through oxidation of sugars resulting favorable use of monosaccharide.

An enrichment technique was used to isolate these isolates on nutrient agar that might have resulted in inaccurate estimation as only $0.1-1 \%$ of the total organisms are culturable on synthetic medium [3]. However, the experiment provided clues on the bacterial communities involved in chlorpyrifos biodegradation.

\section{Conclusive remarks}

This study outlaid the bacterial community involved in the chlorpyrifos biodegradation in a vertisol. The bacterial isolates varied in their $C$ utilization pattern and enzymatic activities. Some bacterial isolates preferred chlorpyrifos as $\mathrm{C}$ substrate. Most of the bacterial isolates possessed decarboxylase, catalase, and oxidase activities. Probably, the chlorpyrifos degradation was 
mediated through these enzymatic activities. Catalase and oxidase were responsible for cleavage of molecule. Carboxylase could have been part of the degradation pathway of chlorpyrifos in vertisol. Preferential utilization of monosaccharides by the isolates indicated efficient degradation of the isolates resulting monosaccharides. Study highlights that chlorpyrifos degrading bacterial community is comprised of different bacterial species which acts synergistically. The present study provided key information on role of bacterial community on chlorpyrifos degradation. However, there is need of further studies to (1) define the biodegradation potential of the individual isolates, (2) examine the function of individual bacterial isolates in chlorpyrifos biodegradation, and (3) elucidate the metagenomic diversity of the un-culturable bacteria and their function in the biodegradation process.

Acknowledgements This research was made possible by financial support from the department of biotechnology (DBT) Govt of India for the project "Biodegradation of pesticides under changing climate and metagenomic profiling of functional microbes (Bio CARe/06/175/2011-12)".

\section{Compliance with ethical standards}

Conflict of interest Authors declare no conflict of interest of any type.

\section{References}

1. Adak T, Munda S, Kumar U et al (2016) Effect of elevated CO2 on chlorpyriphos degradation and soil microbial activities in tropical rice soil. Environ Monit Assess 188:1-12

2. Akbar S, Sultan S (2016) Soil bacteria showing a potential of chlorpyrifos degradation and plant growth enhancement. Braz J Microbiol 47:563-570

3. Amann R, Ludwig W, Schleifer KH (1993) Identification of uncultured bacteria: a challenging task for molecular taxonomists. Am Soc Microbiol News 60:360-365

4. Atlas RM (2010) Handbook of microbiological media, 4th edn. CRC Press, New York

5. Budavari S, O'Neil MJ, Smith A, Heckelman PE (1989) The merck index. Merck, Rahway, NJ

6. Chen S, Liu C, Peng C et al (2012) Biodegradation of chlorpyrifos and its hydrolysis product 3, 5, 6-trichloro-2-pyridinol by a new fungal strain Cladosporium cladosporioides Hu-01. PLoS ONE 7:e47205

7. Crocker FH, Blakeney GA, Jung CM (2016) Complete Degradation of Hexahydro-1, 3, 5-Trinitro-1, 3, 5-Triazine (RDX) by a Co-Culture of Gordonia sp. KTR9 and Methylobacterium sp. JS178. Remediat J 26:51-58

8. Deng S, Chen Y, Wang D et al (2015) Rapid biodegradation of organophosphorus pesticides by Stenotrophomonas sp. G1. J Hazard Mater 297:17-24

9. Dubey G, Kollah B, Ahirwar U et al (2017) Phylloplane bacteria of Jatropha curcas: diversity, metabolic characteristics and growth promoting attributes towards vigor of maize seedling. Can J Microbiol 63:822-833
10. Eissa Fl, Mahmoud HA, Massoud ON et al (2014) Biodegradation of chlorpyrifos by microbial strains isolated from agricultural wastewater. J Am Sci 10:98-108

11. Feng F, Ge J, Li Y et al (2017) Isolation, Colonization, and Chlorpyrifos Degradation Mediation of the Endophytic Bacterium Sphingomonas Strain HJY in Chinese Chives (Allium tuberosum). J Agric Food Chem 65:1131-1138

12. Grovermann C, Schreinemachers P, Riwthong S, Berger T (2017) 'Smart'policies to reduce pesticide use and avoid income tradeoffs: an agent-based model applied to Thai agriculture. Ecol Econ 132:91-103

13. Guodong D, Pei W, Ying T et al (2012) Organophosphate pesticide exposure and neurodevelopment in young Shanghai children. Environ Sci Technol 46:2911-2917

14. Hindumathy CK, Gayathri V (2013) Effect of pesticide (chlorpyrifos) on soil microbial flora and pesticide degradation by strains isolated from contaminated soil. J Bioremed Biodeg 4:2

15. Mallick K, Bharati K et al (1999) Bacterial degradation of chlorpyrifos in pure cultures and in soil. Bull Environ Contam Toxicol 62:48-54

16. Kumar U, Berliner J, Adak T et al (2017) Non-target effect of continuous application of chlorpyrifos on soil microbes, nematodes and its persistence under sub-humid tropical rice-rice cropping system. Ecotoxicol Environ Saf 135:225-235

17. Liu H, Xu Q, Zhang L, Liu N (2005) Chlorpyrifos resistance in mosquito Culex quinquefasciatus. J Med Entomol 42:815-820

18. Lu P, Li Q, Liu H et al (2013) Biodegradation of chlorpyrifos and 3 , 5, 6-trichloro-2-pyridinol by Cupriavidus sp. DT-1. Biores Technol 127:337-342

19. Mekonnen TF, Byrne L, Panne U, Koch M (2017) Transformation products of pesticides: simulation and detection. In: XIX EUROANALYSIS:Europe's Analytical Chemistry Meeting, Stockholm, Sweden

20. Nicolas H, Watson BA, Fellman JK et al (2017) Characterization of Bacillus megaterium, Bacillus pumilus, and Paenibacillus polymyxa isolated from a Pinot noir wine from Western Washington State. Food Microbiol 67:11-16

21. Noor R, Ahmed T, Munshi SK (2017) State of bioremediation in bangladesh: current concept and implementation compared to global approaches. CLEAN-Soil Air Water 45:1

22. Orts A, Cabrera S, Gómez l et al (2017) Use of okara in the bioremediation of chlorpyrifos in soil: effects on soil biochemical properties. Appl Soil Ecol 121:172-176

23. Pino N, Peñuela G (2011) Simultaneous degradation of the pesticides methyl parathion and chlorpyrifos by an isolated bacterial consortium from a contaminated site. Int Biodeterior Biodegrad 65:827-831

24. Racke KD, Laskowski DA, Scultz MR (1990) Resistance of chlorpyrifos to enhanced biodegradation in soil. J Agric Food Chem 38:1430-1436

25. Rayu S, Nielsen UN, Nazaries L, Singh BK (2017) Isolation and molecular characterization of novel chlorpyrifos and 3, 5, 6-trichloro-2-pyridinol-degrading bacteria from sugarcane farm soils. Front Microbiol 8:518

26. Riah W, Laval K, Laroche-Ajzenberg E et al (2014) Effects of pesticides on soil enzymes: a review. Environ Chem Lett 12:257-273

27. Rokade KB, Mali GV (2013) Biodegradation of chlorpyrifos by Pseudomonas desmolyticum NCIM 2112. Int J Pharm Bio Sci 4:609-616

28. Sarnaik SS, Kanekar PP, Raut VM et al (2006) Effect of application of different pesticides to soybean on the soil microflora. J Environ Biol 37:423-426

29. Sharma A, Kumar V, Handa N et al (2018) Potential of endophytic bacteria in heavy metal and pesticide detoxification. In: Plant microbiome: stress response. Springer, Singapore, pp 307-336

30. Sharma B, Saxena S, Datta A, Arora S (2016) Spectrophotometric analysis of degradation of chlorpyrifos pesticide by indigenous 
microorganisms isolated from affected soil. Int J Curr Microbiol App Sci 5:742-749

31. Singh BK, Walker A, Morgan JA, Wright DJ (2003) Effects of soil pH on the biodegradation of chlorpyrifos and isolation of a chlorpyrifos-degrading bacterium. Appl Environ Microbiol 69:5198-5206

32. Tamura K, Stecher G, Peterson D et al (2013) MEGA6: molecular evolutionary genetics analysis version 6.0. Mol Biol Evol 30:2725-2729

33. Thengodkar RRM, Sivakami S (2010) Degradation of chlorpyrifos by an alkaline phosphatase from the cyanobacterium Spirulina platensis. Biodegradation 21:637-644

34. Vischetti C, Monaci E, Cardinali A et al (2008) The effect of initial concentration, co-application and repeated applications on pesticide degradation in a biobed mixture. Chemosphere 72:1739-1743

35. Xiaoyan LIN, Yuhua Z, Qinglin FU et al (2008) Analysis of culturable and unculturable microbial community in bensulfuron-methyl contaminated paddy soils. J Environ Sci 20:1494-1500

36. Xu M-Y, Wang P, Sun Y-J et al (2017) Joint toxicity of chlorpyrifos and cadmium on the oxidative stress and mitochondrial damage in neuronal cells. Food Chem Toxicol 103:246-252
37. Zajic JE, Supplisson B (1972) Emulsification and degradation of "Bunker C" fuel oil by microorganisms. Biotechnol Bioeng 14:331-343

38. Zhang Y, Hou Y, Chen F et al (2011) The degradation of chlorpyrifos and diazinon in aqueous solution by ultrasonic irradiation: effect of parameters and degradation pathway. Chemosphere 82:1109-1115

39. Zhao Y, Wendling LA, Wang C, Pei Y (2017) Behavior of chlorpyrifos and its major metabolite TCP (3, 5, 6-trichloro-2-pyridinol) in agricultural soils amended with drinking water treatment residuals. J Soils Sedim 17:889-900

Publisher's Note Springer Nature remains neutral with regard to jurisdictional claims in published maps and institutional affiliations. 